\title{
The online users' perceptions toward electronic government services
}

\author{
By Mark Anthony Camilleri ${ }^{12}$
}

How to Cite: Camilleri, M.A. (2019). The online users' perceptions toward electronic government services. Journal of Information, Communication \& Ethics in Society. DOI: 10.1108/JICES-09-2019-0102

Purpose: This research examines the individuals' perceived usefulness and ease of use of the government's electronic services (e-government). It also explores the effect of the social influences as well as of the facilitating conditions on the individuals' intentions to use the government's digital and mobile services.

Design/methodology/approach: The researcher has adapted various measuring items from the Unified Theory of Acceptance and Use of Technology and from the Theory of Acceptance Model to investigate the participants' utilitarian motivations to engage with the government's online services. The analysis involved a two-step, structural equation modelling approach that included a confirmatory factor analysis (CFA) that verified the constructs' validity and reliability.

Findings: There was a satisfactory fit for this study's research model. The findings revealed that there were direct and indirect effects that predicted the individuals' readiness to use the e-government services. The results suggest that the respondents' perceived usefulness and ease of use of this digital technology were significant antecedents for their behavioral intention to use it. The strength of these relationships was affected by the moderating variables, including age, gender and experience. Yet, these demographic variables did not have a significant effect on the link between social influences and behavioral intention.

Originality: This study reported that the citizens felt that the e-government systems were useful and easy to use for them. The research participants indicated that they will continue accessing their government's online services. Therefore, this research implies that the public services should continue improving the facilitating conditions including the provision of service quality, user capabilities and their secure accessibility to e-government systems via digital and mobile technologies. In conclusion, this contribution identifies its limitations and suggests possible research avenues to academia.

Keywords: Unified Theory of Acceptance and Use of Technology; Technology Acceptance; Theory of Planned Behavior; Government; Electronic Government; Mobile Government.

\footnotetext{
${ }^{1}$ Associate Professor, Department of Corporate Communication, Faculty of Media and Knowledge Sciences, University of Malta, Malta. Email: mark.a.camilleri@um.edu.mt

2 Tutor in Business and Research Fellow, The Business School, University of Edinburgh, Edinburgh, EH89JS, Scotland.
} 


\section{Introduction}

Many governments and their agencies are increasingly using the information and communication technologies (ICTs) as they are offering electronic services to the general public. The provision of electronic and mobile government services can enhance the effectiveness, economies and efficiencies as online users benefit from faster, more convenient and less costly service delivery (Scott, DeLone \& Golden, 2016). The citizens and businesses who avail themselves of the e-government's and/or mobile-government's (mgovernment) services will facilitate their interactions with the government's public services whilst reducing the administrative burdens of bureaucracy and red tape (Evans \& Campos, 2013). The Internet has enabled the instant access to large volumes of data in real time (Chun, Shulman, Sandoval \& Hovy, 2010). As a result, the citizens will experience faster and more efficient services from the government if they use its electronic and mobile services (Massey, Bromberg \& Manoharan, 2019; Wirtz \& Birkmeyer, 2018). Moreover, they will be reducing their paperwork and the travel requirements to and from the government's agencies and departments, if they provide electronic services to online and mobile users.

However, there are still a number of challenges for the proliferation of e-government and/or m-government services, particularly amongst the most vulnerable groups in society. The provision of the e-government services can possibly exclude individuals who are positioned on the wrong side of the 'digital divide' (Lee \& Porumbescu, 2019; Massey et al., 2019; Van Deursen \& Van Dijk, 2014; 2011). For instance, Massey, et al. (2019) argued that the ease of use of these ubiquitous devices and their usability can possibly enable greater access to egovernment services through mobile technologies if the governments choose to invest in mobile friendly platforms. 
However, some individuals may still not have access to a broadband or mobile internet connection, for various reasons, including; age, disability, limited digital skills and/or lack of financial resources. Alternatively, there may be citizens who live in specific areas such as remote communities where they have limited or no access to the Internet. In these cases, the respective governments ought to deliver their public services through traditional channels, including; front office operations or via toll free telephone numbers. Of course, the face-toface customer services, as well as the provision of a call center facility is more expensive than the provision of e-government and/or m-government services. Therefore, the governments ought to encourage its citizens and the businesses to use their electronic services and/or mobile applications (apps). They may have to offer the facilitating conditions including the relevant infrastructures like broadband technologies, as well as training and development opportunities for online users to entice them to use their e-Government services (Lee \& Porumbescu, 2019; Layne \& Lee, 2001). Notwithstanding, the citizens may be concerned about the safety and security of their personal data, if they are aware that their government is gathering and sharing their personal information to improve its service delivery (Chun et al., 2010). The information that is collected and captured by thegovernments may be exposed to certain risks such as data loss, data corruption, data breach or data theft (Conradie \& Choenni, 2014; Picazo-Vela, Gutiérrez-Martínez \& Luna-Reyes, 2012). As a result, the citizens and businesses may be discouraged to engage with the Government's digital and mobile services as they may be wary about its privacy standards (Bélanger \& Carter, 2008).

In this light, this study addresses a knowledge gap in academia as it explores the online users' intentions to use e-Government systems. This research has adopted valid and reliable measures that were drawn from the Unified Theory of Acceptance and Use of Technology 
(UTAUT) (Zuiderwijk et al., 2015; Wang \& Shih, 2009; Venkatesh, Morris, Davis \& Davis, $2003 ; 2012)$ to investigate the citizens' perceptions on the usefulness and ease of use of the e-government system, in the Scottish context. The research participants were expected to indicate whether they were influenced by other individuals to use the government's electronic services, and to reveal their attitudes on the facilitating conditions that may enable them to engage with the digital technologies (Lee \& Porumbescu, 2019; Layne \& Lee, 2001). Therefore, this research sheds light on the online users' behavioral intentions to use egovernment. At the same time, it explains whether there were moderating effects from the socio-demographic variables, including age, gender and experiences on their citizens' engagement with e-government systems.

\section{Background}

Several governments around the globe are utilizing the digital and mobile technologies to enhance the provision of their public services (EuroParl, 2015; Zuiderwijk Janssen \& Dwivedi. 2015). Digital and mobile services are the facilitating instruments that are enabling all levels of the governments' operations, to better service their citizens, big businesses, small enterprises and non-profit organizations (Wirtz \& Birkmeyer, 2018; Rana \& Dwivedi, 2015; Evans \& Campos, 2013). The-governments are increasingly relying on ICT, including computers, websites and business process re-engineering (BPR) to engage with online users (Isaías, Pífano \& Miranda, 2012; Weerakkody, Janssen \& Dwivedi, 2011). Hence, the delivery of e-government and m-government services may usually demand the public service to implement specific transformational processes and procedures that are ultimately intended to add value to customers (Pereira, Macadar, Luciano \& Testa, 2017). Previously, thegovernments' consumers relied on face-to-face interactions or on telephone communications 
to engage with their consumers. Gradually, many governments had introduced interactive communications as departments and their officials started using the emails to engage with online users. Today, citizens and businesses can communicate and interact with thegovernment departments and agencies in real-time, through virtual call centers, via instantmessaging (IM), graphical user interfaces (GUI) and audio/video presentations.

In the past, the-governments' services were operated in administrative silos of information (EuroParl, 2017). However, the electronic governance involves the data exchange between the-government and its stakeholders, including the businesses as well as the general public (Pereira et al., 2017; Rana \& Dwivedi, 2015; Chun et al., 2010). The advances in interactive technologies have brought significant improvements in the delivery of service quality to online users of the Internet (Sá, Rocha \& Cota, 2016; Isaías et al., 2012). As a result, the egovernment and m-government services have become refined and sophisticated. Thus, the provision of online services is more efficient and less costly when compared to the offline services.

However, there are still many citizens and businesses who for various reasons may not want to engage with the-governments' electronic and/or mobile services (Shareef, Kumar, Dwivedi \& Kumar, 2016; 2014). This argumentation is conspicuous with the digital divide in society as not everyone is benefiting from an equitable access and democratic participation in the Internet or from the e-government systems (Ebbers, Jansen \& van Deursen, 2016; Friemel, 2016; Luna-Reyes, Gil-Garcia \& Romero, 2012; Isaías, Miranda \& Pífano, 2009). The low usage of e-government systems impedes the ability of many governments to connect to citizens (Danila \& Abdullah, 2014). Mensah (2018) held that the government authorities should promote the utilization of user-friendly mobile applications as the majority of citizens 
are increasingly engaging with their smartphones for different purposes, including to access information and services. Many countries around the world have introduced online government portals can be accessed through desktop computers as well as via mobilefriendly designs (Camilleri, 2019a; Ndou, 2004). Massey et al. (2019) posited that the government's electronic services can be integrated among different devices in order to ensure an effective service delivery. These authors also maintained that the citizens are increasingly relying on the features of the mobile technologies as they are always connected to wireless networks. Their portable, mobile devices can provide access to a wide array of public information at any time and in any place (Camilleri \& Camilleri, 2019; Wirtz \& Birkmeyer, 2018; Sareen, Punia, \& Chanana, 2013).

In a similar vein, many citizens may easily access their respective government's online portal via virtual, open networks. They can also receive instantaneous messages and responses from the governments' public service systems in their mobile devices, including smart phones or tablets (Shareef et al., 2016). Therefore, m-governance can possibly enhance the quality of the public services in terms of improved efficiency and cost savings (Madden, Bohlin, Oniki, \& Tran, 2013). Notwithstanding, in the near future, the government's electronic systems will be in a better position to exceed their citizens' expectations, in terms of quality of service (Li \& Shang, 2019). The advances in technology, including the increased massive wireless data traffic from different application scenarios, as well as the efficient resource allocation schemes will be better exploited to improve the capacity of online and mobile networks (Zhang, Liu, Chu, Long, Aghvami \& Leung, 2017). For instance, the fifth generation $(5 \mathrm{G})$ of mobile communication systems is expected to enhance the citizens' service quality as they may offer higher mobile connection speeds, capacities 
and reduced latencies (Osseiran, Boccardi, Braun, Kusume, Marsch, Maternia \& Tullberg, 2014; Zhang et al., 2017).

Nevertheless, despite these technological breakthroughs, there are many citizens who are still reluctant to use the-governments' electronic and/or mobile services as they hold negative perceptions toward public administration (Wirtz \& Birkmeyer, 2018; Shareef, Dwivedi, Stamati, \& Williams, 2014). These individuals are not comfortable to share their personal information online (Van Deursen \& Van Dijk, 2014). They may perceive that egovernment and/or m-government platforms are risky and unsecure (Conradie \& Choenni, 2014; Bélanger \& Carter, 2008). Consequentially, they will decide not to upload their data as they suspect that it can be used by third parties (Picazo-Vela et al., 2012; Bélanger \& Carter, 2008).

\section{The Conceptual Framework and the Formulated Hypotheses}

A review of the relevant literature suggests that there are a number of conceptual frameworks that have been widely used in academia. For example, Davis' (1989) Technology Acceptance Model; Ajzen's (1991) Theory of Planned Behavior and Venkatesh et al.'s (2003) Unified Theory of Acceptance and Use of Technology, among others, have often been validated in highly cited publications in communications and technology-related journals, as various researchers investigated the individuals' readiness to use technologies, in different contexts (Camilleri \& Camilleri, 2019; Venkatesh et al., 2012).

\section{The Individuals' Intentions to Use e-government Services}

The Technology Acceptance Model (TAM) posits that the individuals' intentions to use technology would be preceded by their attitude toward usage, which would in turn be 
determined by their perceptions about the usefulness and the ease of use of the mentioned technologies (Rana, Dwivedi \& Williams, 2013; Jaeger \& Matteson, 2009; Davis, 1989; Davis, Bagozzi \& Warshaw, 1989). Ajzen and Fishbein's (1975) Theory of Reasoned Actions (TRA) argued that the individuals' personal attitudes toward certain behaviors and the subjective norms in society will influence their behavioral intentions as well as their actions. Subsequently, Venkatesh et al. (2003) have amalgamated various constructs from TAM and TRA. These authors have empirically validated them in their Unified Theory of Acceptance and Use of Technology (UTAUT) model. Venkatesh et al. (2003; 2012) reported that the individuals' performance expectancy, effort expectancy, social influences, as well as the facilitating conditions were the antecedents that were affecting their intentions to use the technology. Moreover, they maintained that the behavioral intentions anticipated the actual usage of technology. Notwithstanding, the individuals' experience with the usage of technology moderates this relationship (Park, Nam \& Cha, 2012; Wang \& Shih, 2009; Venkatesh et al., 2003). This argumentation leads to the first hypothesis:

H1: The individuals' intentions to use the e-government systems has a significant effect on their actual usage. Their experience moderates this effect.

\section{Perceived Usefulness of e-government Services}

The perceived usefulness construct measures whether the individuals perceive that the technology will support them in their performance (Camilleri \& Camilleri, 2017a; 2017b; 2019). This measure is closely related to Venkatesh et al.'s (2012) 'performance expectancy', and to Davis, Bagozzi \& Warshaw's (1992) 'extrinsic motivation'; as it emphasizes the importance of utilitarian value. Other studies have also indicated that performance expectancy is a precursor of behavioral intention (Venkatesh et al. 2003). The 
relationship between the individuals' performance expectancy or perceived usefulness of technologies and their behavioral intention to use them will be affected by their gender and/or age (Venkatesh et al., 2012). Hence, the demographic variables can have a moderating role on the individuals' adoption of technology (Camilleri, 2019a; Al-Hujran, Al-Debei, Chatfield \& Migdadi, 2015; Carter \& Bélanger, 2005). Therefore, this study hypothesizes:

$\mathrm{H} 2$ : The individuals perceived usefulness of the e-government systems can have a significant effect on their intentions to use them. Age and gender can moderate this effect.

\section{Perceived Ease of Use}

TAM measured the extent to which the individuals' perceived that the technology is userfriendly and free of effort. Davis (1989) posited that the individuals' perceptions on the ease of use (PEoU) of technology will have an effect on their technology acceptance. Similarly, Venkatesh et al.'s (2003) 'effort expectancy' construct measured the degree of the ease of use of technological systems. Very often, the individuals believed that they will benefit if they use the technologies that are easy to use (Scott et al., 2016). Similarly, the citizens' perceived ease of use is a significant predictor of their intention to use the e-government's services (Carter \& Bélanger, 2005). Therefore, the individuals' perceptions on the ease of use of technology will determine their intentions to use certain technologies. Venkatesh et al. (2012) posited that age, gender and experience influence the causal link between the individuals' effort expectancy and their behavioral intentions to utilize the technology. Hence, this research hypothesizes: 
H3: The individuals' perceived ease of use of the e-government's systems can have a significant effect on their intentions to use them. Age, gender and experience can moderate this effect.

\section{Social Influences}

Individuals may be influenced by other individuals, including their family members, friends and/or by acquaintances, to use certain technologies. Venkatesh et al.'s $(2003 ; 2012)$ social influence construct measured the degree to which individuals believe that they are influenced by others to use technologies. This measure is closely associated with the subjective norms construct that was included in Fishbein and Ajzen's (1975) TRA. It is also conspicuous with Ajzen's (1991) theory of planned behavior (TPB). These theoretical underpinnings suggest that the individuals' social influences are a significant antecedent for their intention to use technologies (Park et al., 2012). Notwithstanding, the demographic variables, including age, gender and experience, can possibly moderate the link between the individuals' social influences and their intentions to engage with technologies (Camilleri, 2019b; Venkatesh et al., 2012). Both genders may respond in different ways to the normative pressures from society. The males and females may be driven by psycho-social phenomena to engage in specific behaviors. Moreover, their age and experience with technologies may also have a moderating effect on the link between the social influences and the individuals' behavioral intentions (Venkatesh et al., 2012). This leads to the fourth hypothesis:

H4: The individuals' social influences can have a significant effect on their intentions to use the e-government's systems. Age, gender and experience can moderate this effect. 


\section{The Facilitating Conditions}

The individuals hold different perceptions on the functionality of the infrastructures that they use (Layne \& Lee, 2001) and on other issues, including the provision of ongoing training and development, user support, and access to technology (Lee \& Porumbescu, 2019; Teo, 2009). Venkatesh et al. (2003) suggested that their 'facilitating conditions' construct measures the degree to which individuals believe that the organizational and technical infrastructures exist to support them in the use of a technology system (p. 453). Venkatesh et al. (2012) posited that individuals may ask support from others. However, they went on to suggest that the link between the individuals' facilitating conditions and their intentions to use technologies will be moderated by the demographic variables, including age and experience. Various studies reported that the older individuals face more difficulty in adopting new technologies (Camilleri \& Camilleri, 2017a; Venkatesh et al. 2012). Moreover, there may be differences amongst the male and female genders on how they perceive that the facilitating conditions will influence their engagement with the technologies. Therefore, age, gender and experience can possibly have a moderate effect on the link between the individuals' facilitating conditions and their behavioral intentions to use the technologies. Thus, this study hypothesizes that:

H5: The individuals' facilitating conditions can have a significant effect on their usage of egovernment systems.

H6: The individuals' facilitating conditions can have a significant effect on their intentions to use e-government systems. Age, gender and experience can moderate this effect. 


\section{The Research Model}

This study hypothesizes that the individuals' perceived usefulness, perceived ease of use, social influences, and facilitating conditions are the antecedents of their intentions to use egovernment services, as illustrated in Figure 1. Moreover, the behavioral intentions will precede their actual usage of this technology.

Figure 1. A Research Model on the Individuals' Intention to Use the e-government Systems

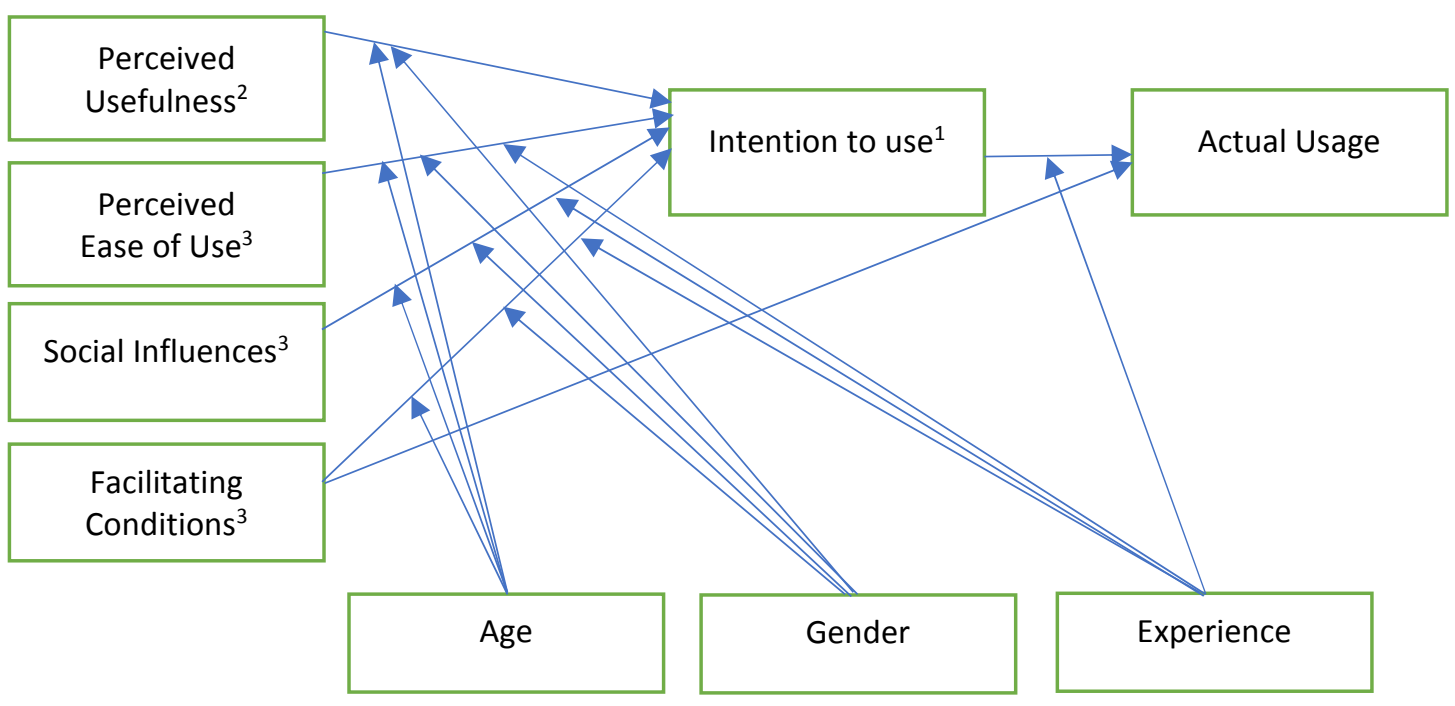

1. Moderated by experience.

2. Moderated by age and gender.

3. Moderating by age, gender and experience.

\section{Methodology}

The respondents were chosen from a database of 25,303 online users who had subscribed to receive promotional information from a group of companies, in Scotland. They had given their consent to be targeted by promotional material from third parties. Therefore, this research complied with the British Economic and Social Research Council (ESRC)'s 
framework for research ethics and with the European Union's GDPR guidelines (EU, 2018). The research participants received emails that comprised a hyperlink to this study's survey questionnaire. The research participants could not take part in this study more than once as their IP address was recorded in the survey system. There were 12,083 hits on the survey link. Of these, 706 respondents have returned the questionnaire that comprised useable data sets.

\section{The Measures}

The respondents have indicated the extent of their agreement with this study's survey items, in a seven-point Likert scale. The responses ranged from $1=$ "strongly disagree" to $7=$ "strongly agree", where 4 signaled an indecision. The survey instrument has adapted measuring items that were drawn from Davis' (1989) TAM and from Venkatesh et al.'s (2003) UTAUT. The constructs included; 'perceived usefulness of technology', perceived ease of use of technology', 'social influences', 'facilitating conditions', 'behavioral intentions' and 'usage of technology'. This study relied on Harman's single factor test to check for the common method variance (CMV). Moreover, the researcher examined the systematic error variances (Sharma, Yetton \& Crawford, 2009).

\section{The Research Participants}

The surveyed respondents gave their socio-demographic details about their 'gender', 'age' and 'experience' in the latter part of the survey questionnaire. The research participants identity remained anonymous and their responses were kept confidential as only aggregate information was used during the analysis of the data. The respondents were expected to disclose their age by choosing one of seven age groups; They confirmed their gender by choosing the 1 or 0 dummy variable. Moreover, they revealed their experience with e- 
government systems (the experience was measured in months). Table 1 presents a description of the profile of the research participants:

Table 1. The demographic profile of the survey respondents

\begin{tabular}{|l|l|}
\hline \multicolumn{2}{|c|}{ Gender } \\
\hline Female & 474 \\
\hline Male & 232 \\
\hline & \\
\hline $\mathrm{N}=706$ & \\
\hline & \\
\hline & \\
\hline & \\
\hline & \\
\hline & \\
\hline & \\
\hline
\end{tabular}

\begin{tabular}{|l|c|}
\hline \multicolumn{2}{|c|}{ Age } \\
\hline 16-25 years & 105 \\
\hline 26-35 years & 163 \\
\hline 36-45 years & 184 \\
\hline 46-55 years & 165 \\
\hline 56-65 years & 62 \\
\hline 66-75 years & 21 \\
\hline More than 76 years & 3 \\
\hline & \\
\hline mean & 37 years \\
\hline N=703 \\
\hline
\end{tabular}

\begin{tabular}{|l|c|}
\hline \multicolumn{2}{|c|}{ Experience } \\
\hline 0-12 months & 32 \\
\hline 13-24 months & 27 \\
\hline 25-36 months & 89 \\
\hline 37-48 months & 343 \\
\hline 49-60 months & 190 \\
\hline 61-72 months & 15 \\
\hline More than 73 months & 10 \\
\hline & \\
\hline mean & 44 months \\
\hline N=706 & \\
\hline
\end{tabular}

\section{Analysis and Interpretation of the Findings}

There were two hundred thirty-two males and four hundred seventy-four females $(n=706)$ who participated in this study. The respondents' 'age' varied, and this was evident in the standard deviation $(\boldsymbol{\sigma})$ of 0.79 . Respondents were also classified into six age groups (16-25; $26-35 ; 36-45 ; 46-55,56-65$ and over 66 years of age). There were three respondents who did not disclose their age in the survey instrument. The majority of the respondents were aged between 36 and 45 years of age $(n=184)$, followed by those aged between 46 and 55 years $(n=165)$. The majority of respondents $(n=343)$ indicated that they have been using the egovernment system between 37-48 months. Whereas, two hundred fifteen respondents had used it for more than 4 years. Generally, the respondents indicated that they agreed with the survey items in the model, as the mean scores were well above the mid-point of 4.0. Moreover, the standard deviations indicated that there was a narrow spread in the 
participants' responses, ranging from 0.3 to 1.4. The skewness and the kurtosis indices were congruent with Kline's (2005) recommendations for the purposes of SEM.

\section{The confirmatory factor analysis (CFA)}

The analysis involved a two-step structural equation modelling that was conducted through AMOS 7.0. A confirmatory factor analysis (CFA) assessed the validity and reliability of the measures. The CFA results indicated the fitness indices and the standard factor loadings. The correlations between the constructs were computed simultaneously. There were certain fitness indices that did not achieve the required level. The factor loading for items PE4 and FC3 were below 0.6. Therefore, these two items were dropped. There was discriminant validity as the model had low modification indices $(\mathrm{MI}<14)$ and the correlation between the exogenous constructs did not exceed 0.85 . The items that had a factor loading less than 0.6 and an R2 less than 0.4 were deleted as they affected the fitness index of the model. The fitness indexes have improved after the necessary modifications. The latest results reported a satisfactory model fit: $\chi^{2}=445.240 ; \chi^{2} / \mathrm{df}=2.98 ; \mathrm{TLI}=.961 ; \mathrm{CFI}=.950 ; \mathrm{RMSEA}=.048$; $\mathrm{SRMR}=.029$

The convergent and discriminant validities of the constructs were inspected to substantiate the rigor of this study. The convergent validity of the formative indicators was carried out by using redundancy analysis. The discriminant validity was assessed by relating the square root of each construct's average variance extracted (AVE) with the off-diagonal correlations. The AVE values were above 0.8, as per Fornell \& Larcker's (1981) recommendations. The composite reliability and internal consistency have exceeded the threshold value of 0.7 as they were also greater than 0.8 as reported in Table 2 . Table 3 presents the discriminant 
validity index that indicated the correlation coefficients as well as the AVEs that were presented as off-diagonal elements (in bold).

Table 2. The Validity and Reliability of the Constructs

\begin{tabular}{|c|c|c|c|c|}
\hline \multicolumn{2}{|c|}{ Construct and Items } & & FL & $\mathbf{C R}$ \\
\hline \multirow[t]{4}{*}{$\begin{array}{l}\text { Perceived } \\
\text { Usefulness }\end{array}$} & PU1 & $\begin{array}{l}\text { I find the e-Government services useful in } \\
\text { my daily life }\end{array}$ & 0.8 & \multirow{3}{*}{0.82} \\
\hline & PU2 & $\begin{array}{c}\text { Using the e-Government services increases } \\
\text { my chances of achieving things that are } \\
\text { important to me. }\end{array}$ & 0.78 & \\
\hline & PU3 & $\begin{array}{l}\text { The-e-Government services help me } \\
\text { accomplish things more quickly }\end{array}$ & 0.65 & \\
\hline & PU4 & $\begin{array}{c}\text { Using the Government services increases } \\
\text { my productivity }\end{array}$ & $\theta .49$ & Deleted \\
\hline \multirow[t]{4}{*}{$\begin{array}{l}\text { Perceived Ease of } \\
\text { Use }\end{array}$} & PEoU1 & $\begin{array}{l}\text { Learning how to use the e-Government } \\
\text { services is easy for me }\end{array}$ & 0.91 & \multirow{4}{*}{0.89} \\
\hline & PEoU2 & $\begin{array}{l}\text { My interaction with the e-Government } \\
\text { services is clear and understandable }\end{array}$ & 0.88 & \\
\hline & PEoU3 & I find the e-Government services easy to use & 0.86 & \\
\hline & PEoU4 & $\begin{array}{l}\text { It is easy for me to become skillful at using } \\
\text { the e-Government services }\end{array}$ & 0.9 & \\
\hline \multirow{3}{*}{$\begin{array}{l}\text { Social Influence } \\
\text { (AVE=0.889) }\end{array}$} & SI1 & $\begin{array}{l}\text { People who are important to me think that I } \\
\text { should use the -Government services }\end{array}$ & 0.79 & \multirow{3}{*}{0.85} \\
\hline & SI2 & $\begin{array}{l}\text { People who influence my behavior think that } \\
\text { I should use the -Government services }\end{array}$ & 0.92 & \\
\hline & SI3 & $\begin{array}{l}\text { People whose opinions that I value prefer that } \\
\text { I use the e-Government services }\end{array}$ & 0.87 & \\
\hline \multirow[t]{4}{*}{$\begin{array}{l}\text { Facilitating } \\
\text { Conditions }\end{array}$} & FC1 & $\begin{array}{l}\text { I have the resources necessary to use the e- } \\
\text { Government services }\end{array}$ & 0.88 & \multirow{3}{*}{0.88} \\
\hline & $\mathrm{FC} 2$ & $\begin{array}{l}\text { I have the knowledge necessary to use the e- } \\
\text { Government services }\end{array}$ & 0.85 & \\
\hline & $\mathrm{FC} 4$ & $\begin{array}{l}\text { I can get help from others when I have } \\
\text { difficulties using the e-Government services }\end{array}$ & 0.74 & \\
\hline & $\mathrm{FC} 3$ & $\begin{array}{c}\text { The-e-Government services are compatible } \\
\text { with other technologies I use }\end{array}$ & $\theta .46$ & Deleted \\
\hline \multirow[t]{3}{*}{$\begin{array}{l}\text { Behavioral } \\
\text { Intention }\end{array}$} & BI1 & $\begin{array}{l}\text { It is very likely that I shall continue using the } \\
\text { e-Government services in the future }\end{array}$ & 0.81 & \multirow{3}{*}{0.91} \\
\hline & $\mathrm{BI} 2$ & $\begin{array}{l}\text { Probably, I will use the e-Government } \\
\text { services in my daily life. }\end{array}$ & 0.82 & \\
\hline & $\mathrm{BI} 3$ & $\begin{array}{l}\text { I will use the e-Government services as } \\
\text { frequently as possible. }\end{array}$ & 0.79 & \\
\hline \multirow{3}{*}{$\begin{array}{c}\text { Usage } \\
(\mathrm{AVE}=\mathbf{0 . 9 0 2}\end{array}$} & U1 & I regularly use the e-Government services & 0.85 & \multirow{3}{*}{0.89} \\
\hline & $\mathrm{U} 2$ & $\begin{array}{l}\text { I search for information on the government's } \\
\text { services through its web pages }\end{array}$ & 0.87 & \\
\hline & U3 & $\begin{array}{l}\text { I access the e-government services through } \\
\text { my mobile device (smartphone or tablet) }\end{array}$ & 0.79 & \\
\hline
\end{tabular}

Note: $\mathrm{AVE}=$ average variance extracted, $\mathrm{FL}=$ factor loadings, $\mathrm{CR}=$ construct reliability. 
Table 3. The Discriminant Validity Index

\begin{tabular}{|c|c|c|c|c|c|c|c|c|c|c|c|c|}
\hline \multicolumn{2}{|c|}{ Construct } & \multicolumn{2}{|l|}{ Items } & \multirow{2}{*}{$\begin{array}{l}1 \\
0.883 \\
\end{array}$} & \multirow[t]{2}{*}{2} & \multirow[t]{2}{*}{3} & \multirow[t]{2}{*}{4} & \multirow[t]{2}{*}{7} & \multirow[t]{2}{*}{8} & \multirow[t]{2}{*}{9} & \multirow[t]{2}{*}{10} & \multirow[t]{2}{*}{11} \\
\hline 1 & $\begin{array}{l}\text { Perceived } \\
\text { Usefulness }\end{array}$ & PU & 3 & & & & & & & & & \\
\hline 2 & $\begin{array}{c}\text { Perceived } \\
\text { Ease of Use }\end{array}$ & PEoU & 4 & $0.512 *$ & 0.9 & & & & & & & \\
\hline 3 & $\begin{array}{c}\text { Social } \\
\text { Influence }\end{array}$ & SI & 3 & -0.725 & 0.675 & 0.889 & & & & & & \\
\hline 4 & $\begin{array}{l}\text { Facilitating } \\
\text { Conditions }\end{array}$ & $\mathrm{FC}$ & 3 & 0.531 & $0.392 *$ & 0.712 & 0.906 & & & & & \\
\hline 7 & $\begin{array}{c}\text { Behavioral } \\
\text { Intention }\end{array}$ & BI & 3 & 0.743 & $0.193 *$ & 0.723 & -0.743 & 0.889 & & & & \\
\hline 8 & Usage & $\mathrm{U}$ & 3 & 0.605 & 0.452 & 0.548 & 0.611 & 0.591 & 0.902 & & & \\
\hline 9 & Gender & GDR & 1 & 0.021 & -0.032 & -0.011 & $0.017 *$ & -0.125 & 0.054 & N/A & & \\
\hline 10 & Age & AGE & 1 & 0.111 & -0.015 & -0.011 & -0.003 & 0.005 & $0.012 *$ & 0.007 & N/A & \\
\hline 11 & Experience & EXP & 1 & 0.03 & $0.022 *$ & -0.017 & $0.011 * *$ & 0.104 & $0.101 *$ & $0.092 *$ & 0.108 & N/A \\
\hline
\end{tabular}

Note: $* \mathrm{p}<0.05 ; * * \mathrm{p}<0.01 ; * * \mathrm{p}<0.001$; all other correlations are insignificant.

Off diagonal factors are correlations and bold diagonal factors are square root of variance shared.

\section{Discussion}

According to the structural equations modeling, there was a satisfactory fit for the research model of this study. The findings indicated that there were highly significant, direct effects on the individuals' intention and usage of e-government technologies. The participants demonstrated that they had utilitarian motives that triggered them to use the government's online services. Overall, the direct effects represented 38 percent of the variance that predicted behavioral intention, whilst the interaction terms explained 67 percent of the variance. In a similar vein, there was 41 percent of the variance that explained the direct effects, whilst 54 percent of the variance comprised the mediating effects on the usage of technology. The results suggest that there were significant moderating influences from the demographic variables, including age, gender and experience that had an effect on the users' engagement with e-government systems. 
The individuals' behavioral intention had a direct effect (0.31) that was highly significant (where $\mathrm{p}<0.001$ ) on their usage of the e-government's services. Moreover, there was a significant $(p<0.05)$, indirect effect $(0.13)$ from the users' experience $(0.13)$ in this relationship. The individuals' perceived usefulness of the e-government's services had a direct effect $(0.32)$ that was very significant $(\mathrm{p}<0.001)$ on their intention to use it. Notwithstanding, there was also a highly significant $(\mathrm{p}<0.01)$ indirect effect $(0.11)$ from the mediating variables, including; age and gender that moderated the perceived usefulness behavioral intention relationship. The research participants' perceived usefulness of the egovernment's services appeared to be the most significant driver that predicted their behavioral intention to use this technology This finding is in stark contrast with Mensah's (2017) study as he reported that the citizens' perceived usefulness of e-government services did not have a significant influence on their intention to use this technology. In this case, the individuals' perceived usefulness of the e-government predicted their intention to use it. The strength of this relationship varied with gender and age such that it was more significant for males and for the younger respondents.

The findings suggest that the individuals' perceived ease of use of the e-government systems $(0.24)$ as well as their social influences $(0.19)$ were significant antecedents for their behavioral intention to use the e-government services, where $\mathrm{p}<0.05$. The link between the respondents' perceived ease of use and their behavioral intention was moderated by gender and age, such that it was more significant for females and for the older respondents. Yet, those effects decreased with experience. On the other hand, this study suggests that there were no significant, mediating effects on the link between the individuals' social influences and their intentions to engage with the e-government systems. Notwithstanding, the facilitating conditions (0.19) had a very significant influence on the individuals' usage of 
this technology (where $\mathrm{p}<0.001$ ). The results also reported that there were significant mediating effects from age, gender, experience in this research model. The significant path coefficients $(\mathrm{p}<0.05)$ within the interaction terms included the mediating variables like: experience (0.14); age and experience (0.15); facilitating conditions and age (0.21); facilitating conditions and experience (0.24) and facilitating conditions, gender and age (0.09) that indirectly predicted behavioral intention. Moreover, behavioral intention and experience (0.17); facilitating conditions and age (0.12); and facilitating conditions, age and experience (0.13) predicted the usage of e-government systems. Similarly, Venkatesh et al.'s (2012) study also reported a significant, direct relationship between facilitating conditions and behavioral intentions. However, their study reported that there was no relationship between facilitating conditions and behavioral intentions when they tested for the moderating effects of age, gender and experience.

\section{Conclusions}

This research adds value to the extant academic literature that investigated the adoption of e-government services. Firstly, this contribution has presented a critical analysis of the relevant theoretical underpinnings on digital and mobile government services. Secondly, the empirical study of this paper has validated the Unified Theory of Acceptance and Use of Technology to better understand the citizens' intention to engage with the Scottish egovernment's services. A survey questionnaire explored the individuals' perceptions toward the usefulness and ease of use of the government's online systems. It investigated whether they were influenced by other individuals to use this technology. Moreover, it determined whether there were facilitating conditions that could have had an effect on their engagement 
with the governments' electronic services. In sum, this research reported that the respondents perceived the usefulness and the ease of use of the e-government systems as these constructs had the highest direct effects on their intention to engage with their government's online technology. In other words, these findings imply that the research participants felt that the e-government systems were useful and easy to use for them. In fact, they indicated that they will continue accessing their government's online services.

These encouraging results suggest that the governments should continue offering online information and value-added services to the general public. Hence, there is scope for many governments to continue improving the facilitating conditions (in terms of the provision of: accurate information; service quality and capability; reliability and secure access to interactive e-government systems; etc.) to entice citizens and businesses to use their digital and mobile services (if any). However, the governments' web sites, e-government and mgovernment systems ought to be well-designed, structured and easy to use. They can possibly offer live chat facilities to support the online users in their queries, or to address their concerns. If they do not offer such interactions in real time, they can still acknowledge the online messages they receive. In addition to e-government, many governments are also offering m-government services that can be accessed via mobile devices, including the smart phones and tablets (Wirtz \& Birkmeyer, 2018; Shareeff et al., 2014, 2016). These ubiquitous technologies provide an instant access to information and services from virtually everywhere.

On the other hand, there are still challenges facing many governments and societies relating to the digital divide amongst citizens. The literature review has explained that there are citizens hailing from different demographic groups from advanced and developing economies, who are still not benefiting from the digital media and/or from their mobile technologies (Mossey et al., 2019). Hence, the governments' responsibility is to ensure that 
the e-government and/or m-government services are widely accessible and have to be easy to use for all citizens. Therefore, the provision of training programs that target the most vulnerable groups in society, can play an important role in this capacity (Lee \& Porumbescu, 2019). Arguably, the way forward is to have more inclusive governments who offer their value-added services through digital and mobile technologies. However, the governments need to ensure that progress is felt by all segments of society.

\section{Limitation and Future Research}

This study has revalidated the unified theory of acceptance and use of technology as it explored the individuals' behavioral intentions to use e-government systems. The number of research participants was more than enough to draw significant conclusions from the results. Nevertheless, the respondents in this study were mostly middle-aged females (their mean age was around 37). Therefore, the findings of this study ought to be replicated amongst other demographic groups in society. Future contributions can reuse the measuring items of this research. Perhaps, they can build on this empirical study by incorporating other constructs including; perceived value, perceived reliability, perceived service quality, satisfaction, secure accessibility, perceived service capability, perceived interactivity and responsiveness, among others, in order to examine the effects of other exogenous constructs on the individuals' behavioral intentions to use the e-government's services in various contexts. There is also scope in conducting qualitative studies to investigate the individual citizens' opinions and beliefs toward the-governments' electronic services. A longitudinal study can possible reveal any changes in the individuals' behavioral intentions to use e gov and/or m gov services, in the long term. 


\section{Acknowledgements}

The researcher thanks the editor of this journal and his reviewers for their constructive remarks and suggestions.

\section{References}

Al-Hujran, O., Al-Debei, M. M., Chatfield, A., \& Migdadi, M. (2015), "The imperative of influencing citizen attitude toward e-government adoption and use", Computers in human Behavior, Vol 53, pp. 189-203.

Ajzen, I. (1991), "The theory of planned behavior", Organizational Behavior and Human Decision Processes, Vol. 50, No. 2, pp. 179-211.

Bélanger, F. and Carter, L. (2008), "Trust and risk in e-government adoption", The Journal of Strategic Information Systems, Vol. 17, No. 2, pp. 165-176.

Camilleri, M. A. and Camilleri, A.C. (2017a), "The technology acceptance of mobile applications in education", In 13th International Conference on Mobile Learning (Budapest, April 10th). Proceedings, International Association for Development of the Information Society.

Camilleri, M.A., and Camilleri, A.C. (2017b), "Digital learning resources and ubiquitous technologies in education", Technology, Knowledge and Learning, Vol. 22, No. 1, pp. 65-82.

Camilleri, M. A. (2019a), "Exploring the Behavioral Intention to Use e-Government Services: Validating the Unified Theory of Acceptance and Use of Technology". 9th International Conference on Internet Technologies \& Society, Lingnan University, Hong Kong. IADIS.

Camilleri, M. (2019b), "The SMEs' technology acceptance of digital media for stakeholder engagement", Journal of Small Business and Enterprise Development, Vol. 26 No. 4, pp. 504-521.

Camilleri, M.A. and Camilleri, A.C. (2019), "The Students' Readiness to Engage with Mobile Learning Apps", Interactive Technology and Smart Education", available at: DOI: 10.1108/ITSE-06-2019-0027 (accessed 5 September 2019).

Carter, L. and Bélanger, F. (2005), "The utilization of e-government services: citizen trust, innovation and acceptance factors", Information Systems Journal, Vol. 15, No. 1, pp. 525.

Chun, S., Shulman, S., Sandoval, R. and Hovy, E. (2010), "Government 2.0: Making connections between citizens, data and government", Information Polity, Vol. 15, Nos. $(1,2)$, pp. 1-9.

Conradie, P. and Choenni, S. (2014), "On the barriers for local government releasing open data”, Government Information Quarterly, Vol. 31, pp. S10-S17.

Davis, F.D. (1989), "Perceived usefulness, perceived ease of use, and user acceptance of information technology", MIS Quarterly, pp. 319-340.

Davis, F.D., Bagozzi, R.P. and Warshaw, P.R. (1989), "User acceptance of computer technology: a comparison of two theoretical models", Management Science, Vol. 35, No. 8, pp. 982-1003. 
Davis, F. D., Bagozzi, R.P. and Warshaw, P.R. (1992), "Extrinsic and intrinsic motivation to use computers in the workplace", Journal of Applied Social Psychology, Vol. 22, No. 14, pp. 1111-1132.

Ebbers, W. E., Jansen, M. G. and van Deursen, A. J. (2016), "Impact of the digital divide on e-government: Expanding from channel choice to channel usage", Government Information Quarterly, Vol. 33, No. 4, pp. 685-692.

EU (2018), "EU Data Protection Rules", https://ec.europa.eu/commission/priorities/justiceand-fundamental-rights/data-protection/2018-reform-eu-data-protection-rules/eu-dataprotection-rules_en

EuroParl (2015), "e-government: Using technology to improve public services and democratic participation", available at: http://www.europarl.europa.eu/RegData/etudes/IDAN/2015/565890/EPRS_IDA(201 5)565890_EN.pdf (accessed 12 August 2019).

EuroParl (2017), "The role of e-government in deepening the single market", available at: http://www.europarl.europa.eu/RegData/etudes/BRIE/2017/608706/EPRS_BRI(2017)6 08706_EN.pdf (accessed 12 August 2019).

Evans, A. M. and Campos, A. (2013), "Open government initiatives: Challenges of citizen participation", Journal of Policy Analysis and Management, Vol. 32, No. 1, pp. 172-185.

Fishbein, M. and Ajzen, I. (1975), "Belief, Attitude, Intention, and Behavior: An Introduction to Theory and Research”, Reading, MA, USA: Addison-Wesley.

Fornell, C. and Larcker, D.F. (1981), "Evaluating structural equation models with unobservable variables and measurement error", Journal of Marketing Research, Vol. 48, pp. 39-50.

Friemel, T. N. (2016), "The digital divide has grown old: Determinants of a digital divide among seniors", New Media \& Society, Vol. 18, No. 2, pp. 313-331.

Isaías, P., Miranda, P. and Pífano, S. (2009), "Critical success factors for web 2.0-A reference framework", In International Conference on Online Communities and Social Computing (pp. 354-363). Berlin, Germany: Springer.

Isaías, P., Pífano, S. and Miranda, P. (2012), "Web 2.0: Harnessing democracy's potential", In Public Service, Governance and Web 2.0 Technologies: Future Trends in Social Media (pp. 223-236). Hershey, USA: IGI Global.

Jaeger, P. and Matteson, M. (2009), "e-Government and Technology Acceptance: The Case of the Implementation of Section 508 Guidelines for Websites", Electronic Journal of EGovernment, Vol. 7, No. 1, pp. 87-98.

Kline, R.B. (2005), "Principles and practice of structural equation modeling" (2nd ed.). New York, USA: Guilford Press.

Layne, K. and Lee, J. (2001), "Developing fully functional E-government: A four stage model", Government Information Quarterly, Vol. 18, No. 2, pp. 122-136.

Lee, J. B. and Porumbescu, G. A. (2019), "Engendering inclusive e-government use through citizen IT training programs", Government Information Quarterly, Vol. 36, No. 1, pp. 6976.

Li, Y. and Shang, H. (2019), “Service quality, perceived value, and citizens' continuous-use intention regarding e-government: Empirical evidence from China", Information \& Management, https://www.sciencedirect.com/science/article/pii/S0378720617306912

Luna-Reyes, L. F., Gil-Garcia, J. R. and Romero, G. (2012), “Towards a multidimensional model for evaluating electronic government: Proposing a more comprehensive and 
integrative perspective", Government Information Quarterly, Vol. 29, No. 3, pp. 324334.

Madden, G., Bohlin, E., Oniki, H. and Tran, T. (2013), "Potential demand for m-government services in Japan", Applied Economics Letters, Vol. 20, No. 8, pp. 732-736.

Mensah, I. K. (2018), "Citizens' Readiness to adopt and use e-government services in the city of Harbin, China", International Journal of Public Administration, Vol. 41, No. 4, pp. 297-307.

Mossey, S., Bromberg, D. and Manoharan, A. P. (2019), "Harnessing the power of mobile technology to bridge the digital divide: a look at US cities' mobile-government capability", Journal of Information Technology \& Politics, Vol. 16, No. 1, pp. 52-65.

Ndou, V. (2004), "E-Government for developing countries: opportunities and challenges", The electronic journal of information systems in developing countries, Vol 18 , No. 1, pp. 1-24.

Osseiran, A., Boccardi, F., Braun, V., Kusume, K., Marsch, P., Maternia, M. and Tullberg, H. (2014), "Scenarios for 5G mobile and wireless communications: the vision of the METIS project", IEEE Communications Magazine, Vol. 52, No. 5, pp. 26-35.

Park, S.Y., Nam, M.W. and Cha, S. B. (2012), "University students' behavioral intention to use mobile learning: Evaluating the technology acceptance model", British Journal of Educational Technology, Vol. 43, No. 4, pp. 592-605.

Pereira, G. V., Macadar, M. A., Luciano, E. M. and Testa, M. G. (2017), "Delivering public value through open government data initiatives in a Smart City context", Information Systems Frontiers, Vol. 19, No. 2, pp. 213-229.

Picazo-Vela, S., Gutiérrez-Martínez, I. and Luna-Reyes, L. F. (2012), "Understanding risks, benefits, and strategic alternatives of social media applications in the public sector", Government Information Quarterly, Vol. 29, No. 4, pp. 504-511.

Rana, N. P., Dwivedi, Y. K. and Williams, M. D. (2013), "Analysing challenges, barriers and CSF of e gov adoption", Transforming Government: People, Process and Policy, Vol. 7, No. 2, pp. 177-198.

Rana, N. P. and Dwivedi, Y.K. (2015), "Citizen's adoption of an e-government system: Validating extended social cognitive theory (SCT)", Government Information Quarterly, Vol. 32, No. 2, pp. 172-181.

Sá, F., Rocha, Á. and Cota, M. P. (2016), "From the quality of traditional services to the quality of local e-Government online services: A literature review", Government Information Quarterly, Vol. 33, No. 1, pp. 149-160.

Scott, M., DeLone, W. and Golden, W. (2016), "Measuring e-government success: a public value approach", European Journal of Information Systems, Vol. 25, No. 3, pp. 187-208.

Shareef, M. A., Dwivedi, Y. K., Stamati, T. and Williams, M. D. (2014), "SQ m gov: a comprehensive service-quality paradigm for mobile-government", Information Systems Management, Vol. 31, No. 2, pp. 126-142.

Shareef, M. A., Kumar, V., Dwivedi, Y. K. and Kumar, U. (2016), "Service delivery through mobile-government (m gov): Driving factors and cultural impacts", Information Systems Frontiers, Vol. 18, No. 2, pp. 315-332.

Sharma, R., Yetton, P. and Crawford, J. (2009), "Estimating the effect of common method variance: The method-method pair technique with an illustration from TAM Research", MIS Quarterly, Vol. 33, No. 3, pp. 473-490. 
Van Deursen, A. and Van Dijk, J. (2011), "Internet skills and the digital divide", New Media \& Society”, Vol. 13 No. 6, pp. 893-911.

Van Deursen, A. J., \& Van Dijk, J. A. (2014), "The digital divide shifts to differences in usage", New Media \& Aociety, Vol. 16 No. 3, pp. 507-526.

Venkatesh, V., Morris, M.G., Davis, G.B. and Davis, F.D. (2003), "User acceptance of information technology: Toward a unified view”, MIS Quarterly, pp. 425-478.

Venkatesh, V., Thong, J.Y. and Xu, X. (2012), "Consumer acceptance and use of information technology: extending the unified theory of acceptance and use of technology", MIS Quarterly, pp. 157-178.

Wang, Y.S. and Shih, Y.W. (2009), "Why do people use information kiosks? A validation of the Unified Theory of Acceptance and Use of Technology", Government Information Quarterly, Vol. 26, No. 1, pp. 158-165.

Weerakkody, V., Janssen, M. and Dwivedi, Y.K. (2011), "Transformational change and business process reengineering (BPR): Lessons from the British and Dutch public sector", Government Information Quarterly, Vol. 28, No. 3, pp. 320-328.

Wirtz, B. W. and Birkmeyer, S. (2018), "Mobile-government Services: An Empirical Analysis of Mobile-government Attractiveness", International Journal of Public Administration, Vol. 41, No. 16, pp. 1385-1395.

Zhang, H., Liu, N., Chu, X., Long, K., Aghvami, A. H., \& Leung, V. C. (2017). Network slicing based $5 \mathrm{G}$ and future mobile networks: mobility, resource management, and challenges. IEEE Communications Magazine, 55(8), 138-145.

Zuiderwijk, A., Janssen, M. and Dwivedi, Y.K. (2015), “Acceptance and use predictors of open data technologies: Drawing upon the unified theory of acceptance and use of technology", Government Information Quarterly, Vol. 32, No. 4, pp. 429-440. 